\title{
ISTIȘḤĀB SEBAGAI SOLUSI PEMECAHAN MASALAH KEKINIAN
}

\author{
Maskur Rosyid \\ Sekolah Tinggi Ekonomi Syariah (STES) Islamic Village \\ Komplek Pendikan Islamic Village, Jl. Islamic Raya, Kelapa Dua, Klp. Dua, Tangerang, \\ Banten 15810 \\ e-Mail:Masykurxrejo@gmail.com
}

\begin{abstract}
Abstrak: Dinamisasi hukum Islam bisa dicapai dengan menekankan sisi kemaslahatan sebagai pertimbangan utama penetapan hukum. Salah satu upaya yang dapat dilakukan adalah dengan meninjau ulang istișhāb sebagai dalil hukum, yaitu menetapkan sesuatu berdasarkan status asal. Adakalanya asal segala sesuatu adalah mubah, bebas dari tuntutan, hukum asal masih relevan, dan adakalanya sifat asal adalah tetap. Istișhāb dapat diterapkan pada banyak kasus, baik bidang hukum keluarga, hukum pidana, hukum perdata, maupun hukum ekonomi. Lebih dari itu, nilai penting dan kesesuaian prinsip istișhāāb dengan asas hukum di Indonesia (asas praduga tak bersalah), asas legalitas, dan prinsip nullum delictum nulapoena sine praevia leg poenali menjadikannya penting untuk diketahui lebih lanjut.
\end{abstract}

Kata Kunci: istișhāab, Hukum Islam, asas hukum, kemaslahatan

Abstract: The dynamics of Islamic law can be achieved by emphasizing the benefit side as the main consideration in determining the law. One effort that can be done is to review istișhäb as a legal argument, which is to set something based on the status of the origin. Sometimes the origin of something is allowed to be done (mubab), free from demands, the law of origin is still relevant, and sometimes the nature of origin is permanent. Istișhāb can be applied in many cases, both in the fields of family law, criminal law, civil law and economic law. Moreover, the conformity of the principle of istibäb with the principles of law in Indonesia (the principle of presumption of innocence), the principle of legality, and the principle of nullum delictum nulapoena sine praevia leg poenali are making it important to be discussed further.

Keywords: istiṣhāb, Islamic law, legal principles, benefit

pada perjalanannya berpengaruh besar

\section{Pendahuluan}

Penunjukan Muadh bin Jabbāl oleh Nabi saw. untuk mengemban tugas ke Yaman ${ }^{1}$, dianggap sebagai dasar utama aktivitas ijtihad. Rekomendasi Nabi saw. tersebut terhadap aktivitas penalaran atas nash. Lebih dari itu, Ibn Rushd pernah mengatakan bahwa problematika sosial yang dihadapi manusia kian hari kian banyak sedangkan secara kuantitas, ayat

\footnotetext{
${ }^{1}$ Aḥmad ibn Hanbāl, Musnad Ahmad Ibn Hanbäl (Beirut: Dār al-Kutub al-Islāmiyyah, 1993), Vol. IV, 252.
} 
dan hadis terbatas jumlahnya. ${ }^{2}$ Keadaan demikian, sebagaimana dilakukan oleh Muadh, menuntut juris muslim untuk senantiasa mengoptimalkan peran akal dalam merumuskan sebuah hukum. Hukum Islam diproyeksikan untuk kemaslahat-an, kebaikan, dan keadilan manusia, baik di dunia maupun di akhirat. $^{3}$

Hukum Islam menjawab perubahan sosial. Hal ini secara nyata menghendaki ijtihad yang proporsional dan prefesional. Sehingga hukum Islam tetap dinamis, responsif, tidak keting-galan jaman, dan adaptif. ${ }^{4}$ Sekali lagi, bahwa aktivitas ijtihad harus senantiasa digalakkan. Jargon Islam șälih li kulli zamān wa makān bisa nyata terwujud dan tidak hanya menjadi pepatah kosong tanpa makna.

Ijtihad dilakukan dengan tetap mengacu kepada sumber-sumbernya. Adapun sumber hukum Islam dalam kajian usul fikih terbagi menjadi dua

2 Ibn Rushd, Bidāyah al-Mujtabid wa Nibāyah alMuqtașid (T.tp: Dār al-Kutub al-'Arabiyah, t.th), 2. ${ }^{3}$ Muștafă Za’id, al-Mașlahah fi al-Tasbri' al-Islämi wa Najm al-Din al-Tüfì (ttp: Dār al-Fikr al-'Arābī, 1954), 46. Ḥusayn Hamīd Hasān, Nazariyah alMașlaḥah (Kairo: Dār al-Nahụahah al-'Arābiyah, 1971), 529. 'Abd al-Wahhāb Khallāf, Mașādir alTashri' al-Islämi fi mā lā Nașsa fí bà (Kairo: Ma'had al-Dirāsāt al-'Arabiyyah al-'Āliyah, 1955), 185. Abū Isḥaq Ibrāhīm ibn Mūsā al-Lakhmi AlShāțibī, Al-Muwāạaquat fi Ușūl al-Aḥkām (Kairo: Dār al-Fikr, 1341 H), I: 38.

${ }^{4}$ Ridwan, "Istiṣhāāb dan Penerapannya dalam Hukum Islam”, al-Manähij Jurnal Kajian Hukum gradasi, muttafaq 'alayh dan mukbtalaf fìh. Sumber yang muttafaq 'alayh terdiri dari AlQur'an, Hadis, Ijmā', dan Qiyās, sedangkan yang dipersilihkan penggunaannya yaitu istihsān, istișlāh, istiṣhāb, 'urf, sadd aldhari'ah, shar' man qablanā, madhhab șaḥabi, dan sebagainya.

Istiṣhāb termasuk salah satu dalil hukum yang dipersilihkan penggunaannya. Bagi para pengguna istiṣhāb, mereka beranggapan bahwa istiṣhāb merupakan alternatif penentu hukum ketika sumber yang disepakati tidak dapat menjawab persoalan. Karena itulah, pada tulisan ini, akan dikemukakan nilai penting istiṣhāab sebagai dalil hukum dan bagaimana kesesuainnya dengan asas dan permasalahan kekinian.

Tulisan ini disusun dengan sistematika sebagai berikut. Pertama definisi iistiṣhāab. Hal ini dianggap penting agar tidak terjadi ambiguitas pemaknaan. Kedua pro-kontra aplikasi istișhāab, ketiga kaidah turunan dari

Islam, Vol. v. No. 1, Januari 2011, 1. Dinyatakan bahwa lapangan ijtihad terbagi menjadi dua macam, pertama; persoalan yang sudah ada ketentuan nashnya namun masih bersifat dugaan. Penalaran yng digunakan untuk macam ini adalah penelitian dalam rangka menemukan makna ayat, seperti 'am dan khās, al-mutlaq wa al-muqayyad. Kedua; persoalan yang sama sekali belum ada ketentuan nashnya. Dalam hal ini digunakan perangkan istihsān, istiṣlāh, istișhāb, dan sebagainya. Lihat juga; Mușțafā Mụ̣ammad alZarqā, Hukum Islam dan Perubahan Sosial (Jakarta: Rioracipta, 2000), 45. 
dalil istiṣhāb, dan keempat istiṣhāb menjawab problematika sosial kontemporer dan kesesuaiannya dengan asas hukum positif di Indonesia.

\section{Seluk Beluk Istișhāb}

Secara lughawi, istiṣhāb dimaknai dengan

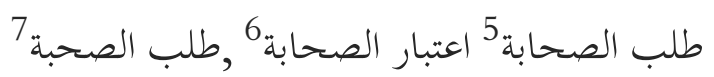

Șụbah dimaknai dengan membandingkan sesuatu kemudian mendekatkannya. Dengan demikian, berdasarkan makna Bahasa tersebut, dipahami bahwa istișhāb yaitu mendekatkan suatu peristiwa dengan hukum tertentu dengan peristiwa lainnya, sehingga keduanya dinilai sama status hukumnya.

Istișhāb secara istilah dimaknai secara berbeda-beda oleh para tokoh sebagai berikut. Al-Ghazzālī memaknai istiṣhāāb dengan
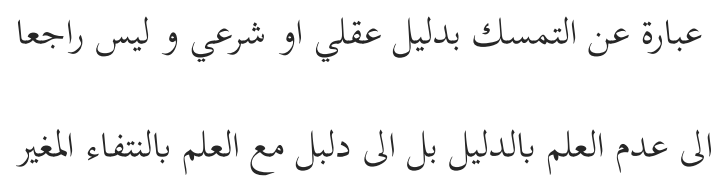

5 'Alī Hasaballāh, Ușūl al-Tashrì' al-Islāmì (Kuwait, Dār al-Ma’ārif, t.th), 197.

6 'Abd al-Wahhāb Khallāf, Ilm Ușūl al-Fiqh (Jiddah, al-Haramayn, 2004), 91.

7 'Abd al-'Azīz al-Rab'iyyah, Adillät al-Tashrì' alMukhtalaf fi al-Iḥtijāj fỉhā (Beirut: Muassasāt alRisālāt, 1979), 275.
او مع ظن انتفاء المغير عند بذلا لجهد في البحوث<smiles>[Li][Mg][Mg]</smiles>

Artinya, tetap berpegang teguh dengan dalil akal atau dalil syar'i, bukan karena tidak mengetahui adanya dalil, melainkan karena mengetahui tidak adanya dalil yang mengubahnya setelah berusaha keras mencari.

Sedangkan menurut 'Abd al-'Azīz alBukhārī, istiṣhhāb adalah

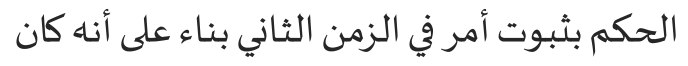

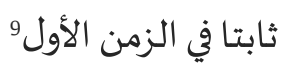

yaitu menyatakan tetap adanya sesuatu pada masa kedua karena sesuatu tersebut memang ada pada masa partama. Ibn alQayyim al-Jauziyyah mengatakan bahwa istiṣhāa sebagai

استدامة إثبات ما كان ثابتا أو نفي ما كان منفيا10 Menetapkan keberadaan sesuatu yang sudah ada sebelumnya dan meniadakan keberadaan sesuatu yang memang tidak ada sebelumnya. Sementara menurut 'Abd al-Wahhāb Khallāf, Istiṣh ạb adalah

8 Abū Hamīd Muhammad ibn Muhammad alGhazzālì, Al-Mustașfā Min Tlm al-Uṣūl (Beirut: Dār al-Kutub al-'Ilmiyah, 1993), 410

9 'Abd al-'Azīz ibn Muḥammad al-Bukhārī, Kashf al-Asrär 'An Ușül Fakehr al-Isläm al-Bazdwì (Beirut: Dār al-Kitāb al-'Arabī, t.th), Vol. 2, 377.

${ }_{10}$ Ibn Qayyim al-Jawziyyah, I'läm al-Munaqqi ìn 'An Rabb al-'Álamin (Beirut: al-Maktabah al'Așriyyah, 2003M), Vol. 1, 247. 
استبقاء الحكم الذي ثبت بدليل في الماضي قائما في الحال

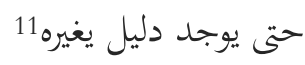

yaitu menetapkan suatu hukum yang telah ada dalilnya sejak dahulu sampai sekarang sampai dengan adanya dalil lain yang mengubahnya.

Sedangkan al-Shawkānī mendefinisikan istișhāb sebagai tetapnya sesuatu selama belum ada dalil lain yang mengubahnya. ${ }^{12}$ Senada dengan itu definisi diberikan oleh 'Alī 'Abd al-Kāfĩ alSubkī sebagai menetapkan hukum atas masalah hukum yang kedua berdasarkan hukum yang pertama karena setelah dilakukan kajian yang komprehensif tidak ditemukan dalil yang mengubah-nya. ${ }^{13}$

Berdasarkan beberapa definisi di atas, dapat dipahami bahwa prinsip istiṣhāb adalah member-lakukan hukum lama selama belum ada hal lain yang mengubahnya. Sehingga pola istișhāb bukan menciptakan hukum baru, melainkan memertahankan dan melestarikan hukum lama.

Terdapat tiga unsur pokok dalam penerapan istiṣhāb, yaitu segi waktu,

\footnotetext{
11 'Abd al-Wahhāb Khallāf, Mașādir al-Tasbri' alIslämì fì Mà Là NașȘa fì hā, 151

12 Muḥammad Ibn 'Alī Ibn Muḥammad alShawkānī, Irshäd al-Fukbül ilā Tahquiq Tlm al-Ușül (Beirut: Dār al-Fikr, 1992), Vol. 1. 396.

13 'Alī 'Abd al-Kāfī al-Subkī, al-Ibbäj (Beirut: Dār al-Kutub al-'Tlmiyyah, 1404 H), 173.
}

ketetapan hukum, dan dalil hukum. ${ }^{14}$ Dari sisi waktu, istiṣhāab menghendaki keterhubungan tiga waktu, masa lalu, masa sekarang, dan masa yang akan datang. Hukum pada masa sekarang dan yang akan datang akan tetap langgeng selama hukum pada masa lalu tidak ada apapun yang mengubahnya. Oleh karena-nya, ketiga waktu tersebut saling berkait. Sisi ketetapan hukum menghendaki dua hal, menetapkan (ithbät) dan melarang (nafy). Sementara sisi dalil hukum, berkaitan dengan sisi waktu sebagaimana disebut di atas. Dalil hukum pada masa lampau akan tetap dilestarikan pada masa sekarang dan akan datang manakala tidak ada yang mengubahnya. Pengetahuan tentang dalil menjadi hal penting bagi aplikasi istișhāb.

Itiṣhāb, dalam hal ini mengacu pada definisi-definisi di atas, menurut Aḥmad Muhammad Musarawah mempunyai tiga rukun (sesuatu yang wajib ada), sebagai berikut. ${ }^{15}$

1. Yakin, yaitu keyakinan terhadap keberadaan hukum yang telah ada.

14 Jaih Mubarok, Metodologi Ijtibad Hukum Islam (Yogyakarta: UII Press, 2002), 135.

15 'Awni Ahmad Muḥammad Musarawah, alIstișhäb, Hujjizyatuh Wa Atbrub Fi al-Ahkäm alFiqhiyyah (Nablis: t.tp, 1424 H/2003 M), 28. 
2. Ragu, yaitu ragu terhadap berlakunya hukum tersebut pada masalah yang ada.

3. Adanya keterkaitan antara apa yang diyakini dengan apa yang diragukan.

Hal ini agak berbeda dengan pendapat Muḥammad Taqī al-Ḥākim yang menyatakan bahwa istiṣhāb mempunyai tujuh rukun ${ }^{16}$ yaitu, 1) Yakin terhadap realitas hukum, 2) adanya keraguan sebagai bandingan atas sifat yakin, 3) adanya kesatuan keterikatan antara realitas yang diyakini dengan realitas yang diragukan, 4) keraguan dan keyakinan tersebut memang benar ada (factual), 5) adanya kesatuan masalah antara yang diyakini dengan yang diragukan, baik dari sisi tema, obyek, maupun tingkatan permasalahan, 6) adanya pertaitan waktu antara hal yang diyakini dengan yang diragukan, dan 7) keyakinan tersebut lebih dahulu ada sebelum keraguan.

Adapun syarat-syarat istiṣhāb yang harus ada agar dapat digunakan sebagai dalil, yaitu: ${ }^{17}$

1. Pengguna istiṣhāb telah mengerahkan seluruh kemam-puannya untuk mencari bukti yang mengubah hukum yang semula ada.

16 Muḥammad Kamal al-Dīn Imām, Ușül al-Fiqh al-Islāmì (Beirut: Muassasah al-Jāmi'iyyah li aldirāsah wa al-Shu'ūn wa al-Tawzi', 1996), $237-$ 238.
2. Setelah mengerahkan seluruh kemampuannya, pengguna istị̣hāb tidak menemukan bukti yang mengubah hukum yang telah ada.

3. Hukum lama yang dijadikan sebagai pijakan istiṣhāa benar adanya, baik dari dalil shar'i ataupun dari dalil akal. Artinya, bukan hanya sekedar dugaan.

4. Hukum lama yang dijadikan sebagai pijakan istișhāb bersifat mutlaq (umum). Artinya, dalil lama tersebut tidak menunjukkan keberlakuan dirinya secara terus-menerus, tidak pula menujukkan ketidakberlakuannya sampai batas waktu tertentu. Jika demikian halnya maka itu tidak disebut menggunakan istiṣhāb, melainkan mengunakan dalil tersebut.

5. Tidak terjadi kontradiktif antara istiṣhāb dengan nash yang ada. Bila terjadi kontradiktif antara keduanya, maka yang didahulukan adalah apa yang tertera pada nash, karena nash memiliki kekuatan hukum yang lebih tinggi dibandingkan dengan istiṣhāb.

\section{Sejarah Perkembangan Istișhāa}

Secara de facto, eksistensi istiṣhāb sudah ada di dalam nash, hanya saja tidak bernama. Contoh istișhāb dalam Al-

17 'Awni Ahmad Muḥammad Musarawah, alIstișhāab, Hujjizyatuh Wa Atbrub Fi al-Ahkeam alFiqbiyyah, 19. 
Qur'an seperti dalam kasus ditolaknya kesaksian orang yang menuduh perempuan baik-baik (muhșanāt) berbuat zina, tetapi tidak dapat menunjukkan empat orang saksi, Al-Qur'an Surah alNūr Ayat 4 menyatakan “...walā taqbalū lahum shahādatan abadan...(janganlah kamu terima kesaksian mereka untuk selamalamanya". Ayat ini menegaskan bahwa kesaksian qädzif (si penuduh) tidak dapat diterima. Masa berlakunya penolakan kesaksian mereka, menurut 'Abd alWahhāb Khallāf ${ }^{18}$, tidak hanya terbatas pada saat itu, melainkan berlaku sepanjang masa. Hal ini dipahami dari kata abadan yang berarti selamaselamanya. Tentu saja selama tidak ada hal lain yang membatalkannya yakni melakukan taubat dan memperbaiki diri. Ayat di atas juga secara tersirat menjelaskan bahwa seorang muslim pada dasarnya 'iffah, terjaga dari melakukan perbuatan zina, karena akal dan agama yang dimilikinya, menahan dirinya dari melakukan perbuatan buruk tersebut. ${ }^{19}$ Jadi, jika orang yang menuduh tidak dapat mendatangkan saksi-saksi untuk memperkuat tuduhannya, maka selama itu pula seorang muslim/muslimah tetap

18 'Abd al-Wahhāb Khallāf, Mașädir al-Tashri' alIslämì fì Mà Là NașSa fì hā, 151

${ }^{19}$ Hefaìz al-Dīn al-Nusayfí, Kashf al-Asrār (Beirut: Dār al-Kutub al-Ilmiyah, 1986), Vol II. 452. pada kondisinya semula yakni terhindar dari melakukan hal-hal yang dilarang.

Contoh lain istiṣhāâ, seseorang yang telah berwudu, menurut Nabi saw. juga tetap dalam keadaan semula, yakni suci dari hadas, selama ia tidak mendengar "suara" atau mencium "bau" (karena angin yang keluar dari lobang pelepasan). Lebih lanjut Nabi saw. menyatakan: "Apabila salah seorang diantara kamu merasakan sesuatu pada perutnya kemudian merasa ragu apakah sudah keluar sesuatu atau tidak, maka janganlah ia keluar dari mesjid sampai ia benar-benar mendengar "suara" atau mencium "bau" yakni ia benar-benar yakin dengan keluarnya sesuatu dengan terdengarmya suara yang keluar (angin) atau terciumnya bau (kentut)'”20

Ayat dan hadis di atas menjelaskan bahwa terdapat indikasi bahwa istiṣhāh, dalam arti hakikat tanpa nama, sudah ada sejak masa Nabi saw., demikian pula pada masa berikutnya yakni masa sahabat dan tabi'in. Ijtihad sahabat mengandung arti luas yakni tidak terbatas pada qiyās, istiḥsān dan maslahat an sich, namun juga mencakup sadd al-zarāi', 'urf dan istiṣhāab. Hanya saja, dalam hal ini, Muḥammad Mūsā Tuwanā tidak menggunakan kata

\footnotetext{
20 Al-Nawāwī, Sharh Muslim (Beirut: Dār alKutub al-'Ilmiyah, 1986), Vol. IV. 45.
} 
istịṣhāb, melainkan al-barāah al-așliyyah. ${ }^{21}$ Mūsā Tuwanā menjelaskan bahwa dalam sebuah peristiwa di mana seorang wanita yang sedang dalam masa iddah, menikah dengan lelaki lain, Umar ibn Khattab memberikan fatwa bahwa lelaki itu tidak boleh menyetubuhi wanita tersebut (melakukan hubungan suami isteri) selamanya (hurmah mu'abbadah). Hal ini, menurut Umar, agar tidak terjadi penyimpangan terhadap perintah Allah, sekaligus menjaga keturunan (hifdz, alnas). Sebaliknya, 'Alī ibn Abī Țālib memberikan fatwa yang berbeda dengan Umar. Menurutnya, lelaki tersebut boleh saja menggauli wanita itu jika ia mau, tentu saja setelah masa iddahnya berakhir. Umar, dalam menyelesaikan kasus ini, berpegang pada al-maslahah al-mursalah. ${ }^{22}$ Sedangkan Ali berpegang pada al-baräah al-așliyyah. ${ }^{23}$ Pendapat Ali ini didasarkan pada keumuman Surah Al-Nisā’’ 3 dan 24. "...maka nikabilah wanita-wanita lain yang kamu senangi dua, tiga atau empat..."

"...dan dihalalkan bagi kamu selain hal yang demikian itu (yaitu) mencari isteri-isteri dengan hartamu untuk dinikabi secara sab bukan untuk beritina..."

\footnotetext{
21 Muḥammad Mūsā Tuwana, al-Ijtihād (Mesir, Dār al-Kutub al-Hadīthah, 1971), 40.

22 Lebih lanjut lihat Abū Zahrah, Tärikh alMadhāhib al-Islāmiyah (Beirut: Dār al-Fikr, tt.), Vol. II. 20-21.
}

Pada masa setelah sahabat, sebagian besar tabi'in berpendapat bahwa segala sesuatu pada dasarnya adalah dibolehkan (ibähah), selama tidak ada dalil nash yang melarangnya. Hal ini dimaksudkan untuk memberikan kemudahan sekaligus menghindarkan kesulitan. Pendapat ini diambil dari perkataan mereka sendiri, di antaranya Said ibn al-Musayyab (w. 94 H), Salim ibn Umar, Shuraih al-Qāḍ̄̄, 'Ațāa' ibn Ribāh, Zuhri, dan 'Umar ibn 'Abd al'Azīz (w. 101 H). Mereka menyatakan bahwa mendengar nyanyian dan alat musik rebana tidaklah dilarang (halal) selama tidak mengajak dan membawa kepada kemunkaran serta tidak memalingkan diri dari melaksanakan kewajiban seperti halnya nyanyian yang dapat memalingkan hati dan menimbulkan rangsangan. Mendengar nyanyian itu dibolehkan selama tidak ada nash yang mengharamkannya. Menurut Salam Madkur, pendapat seperti ini juga telah dianut oleh sebagian sahabat sebelumnya. Ibn al-Musayyab juga membolehkan membaca Al-Qur'an bagi orang yang sedang dalam keadaan junub dengan syarat tidak menyentuh mushafnya. ${ }^{24}$

\footnotetext{
${ }^{23}$ Muḥammad Mūsā Tuwana, al-Ijtihād, 40.

${ }^{24}$ Muḥammad Salam Madhkūr, al-Ijtihād Fī Tashrī' al-Islāmī (Kairo: Dār al-Nahḍah al-'Arabiyah, 1992), Vol I. 69.
} 
Istiṣhāb, sampai pada masa Mālik (w.179 H), belum terkonstruksi secara jelas. Sekalipun demikian, menurut Mūsā Tuwana, salah satu tariqah al-ijtihäd yang dilakukan Mālik adalah menggunakan istiṣhăab. ${ }^{25}$ Contoh kasus dalam hal ini adalah masalah talak. Apabila seorang suami ragu, apakah ia telah menceraikan isterinya atau belum, maka diambil hukum asal yakni tetap dalam pernikahan. Maknanya, talak tidak terjadi. Namun, jika ia yakin telah menceraikan isterinya tetapi ragu apakah telah menjatuhkan talak satu, dua atau tiga, maka dihukumkan bahwa ia telah menjatuhkan talak tiga. ${ }^{26} \mathrm{Hal}$ ini karena talak terjadi dengan keyakinan. Di sisi lain diperoleh keraguan (shakk) tentang tetapnya ruju', sedangkan ruju' tidak dapat ditetapkan dengan keraguan. Apabila dipertanyakan lebih jauh, bagaimana konsep baku istiṣhāb yang dimaksud oleh Mālik? Pertanyaaan seperti ini tampaknya memang sulit terjawab. Dari beberapa literatur yang ada, tidak ditemukan secara jelas jawaban mengenai hal ini. Jika demikian, pada masa siapa istiṣhāb telah mempunyai bangunan sendiri? Menurut Noel J. Coulson, dalam

\footnotetext{
${ }_{25}$ Muḥammad Mūsā Tuwana, al-Ijtihād, 40.

26 Ibn Hazm al-Andalusī, Al-Iḥkàm Fì Ușūl alAhkām (Kairo: Dār al-Hadis, 1992), Vol V. 7.

27 Noel J. Coulson, A History of Islamic Law (Edinburgh: University Press, 1987), 92.
}

menjawab berbagai persoalan serta menghindari segala sesuatu yang dapat merusak hukum Tuhan, al-Shāfi'̄̄ tidak menggunakan konsep istiḥsān dan istișläh, melainkan istiṣhāăb. Dengan konsep ini ia mencoba mencari suatu hubungan dan prinsip pembuktian dengan jalan mengukuhkan peristiwa-peistiwa yang dianggap telah memiliki asal-usul atau sumber yang sah menurut hukum disertai dengan pengakuan eksistensinya, hingga terlihat hal-hal yang berlawanan. ${ }^{27}$ Salah satu contoh mengenai hal ini, adalah pendapat al-Shāfi'ì mengenai kebolehan dalam penjualan 'araya (menjual buah kurma yang masih berada di pohon dengan pembayaran kurma kering seperti barter). Al-Shāfi'ī menggunakan istiṣhāe dalam menyelesaikan masalah ini, yakni tetap memberlakukan hadis yang diriwayatkan Zaid ibn Thabit mengenai kebolehan jenis barter ini sebagai sebuah pengecualian. ${ }^{28}$ Penggunaan istișhāb oleh al-Shāfi'ì dalam kasus ini, menurut Aḥmad Hasan, bukanlah dalam pengertian yang baku melainkan dalam pengertian non teknis. ${ }^{29}$ Bahkan dalam kasus-kasus lain, al-Ghazzālī menyatakan

\footnotetext{
28 Al-Shāfi'î, al-Umm (Kairo: tp, 1325), Vol. VII. 182.

29 Ahmad Hasan, Pintu Ijtihad Sebelum Tertutup (Bandung: Pustaka, 1984), 199.
} 
bahwa al-Shāfi'i berpegang (tamassak) pada istișhāb dan dalil akal, tidak dengan dalil ijmâ’.30 Hanya saja, apabila ditelusuri lebih jauh, tidak ditemukan kata istișhāb dalam al-Risälabnya.

Istișhāb dalam arti yang jelas, baru dijumpai dalam tulisan Muḥammad ibn 'Alī al-Bașrī (w.436 H). Menurutnya, istị̣hāb al-ḥal adalah hukum yang tetap pada suatu kondisi dari berbagai kondisi yang ada, sampai berubahnya kondisi tersebut. Contoh istișhāb yang digunakan adalah mengenai kewajiban berwudu bagi orang yang melakukan tayammum, apabila ia menemukan air. ${ }^{31}$

Dalam kitab al-Luma', contoh yang sama dengan di atas, juga dinyatakan oleh al-Fairuzabadī (w.476 H). Bahkan ia menisbahkan hal ini sebagai perkataan alShāfi'ì. Lebih lanjut ia membagi istiṣhāa alḥălmenjadi dua bagian yakni istișhāa al-ḥāl al-'aql dan istiṣhāb al-ḥāl al-ijmā'. Ia menambahkan bahwa istiṣhāb dapat dipakai sebagai dalil, baik dalam menetapkan hukum (ithbāt) maupun meniadakan hukum (al-nafy).32 Sampel yang kerap dipergunakan adalah perihal

${ }^{30}$ Abū Ḥamid al-Ghazzālī, al-Mustaşā Fì Tlm alUșūl, 159.

31 Muḥammad ibn 'Alī al-Bașri, al-Mu'tamad Fì Ușūl al-Figh (Damshiq: Dār al-Fikr, 1965), Vol II. 884

${ }^{32}$ Ibrāhīm ibn 'Alī al-Fairuzabadī, al-Luma' Fi Ușūl al-Fiqh (Beirut: Dār al-Kutub al-'Ilmiyah, 1985), 122.

http://dx.doi.org/10.18592/sy.v18i1.2125 orang hilang (al-mafqüd). Orang yang hilang dan tidak diketahui apakah ia masih hidup atau sebaliknya, maka berdasarkan istiṣhāb, ia dihukumi masih hidup, selama tidak ada fakta yang menunjukkan kematiannya. Oleh karena itu, jika ada ahli warisnya yang meninggal dunia, maka ia berhak memperoleh warisan. Demikian pula halnya dengan wasiat. Di sisi lain, hartanya masih tetap berada dalam tanggungjawabnya, tidak boleh diwariskan. Bila ia mempunyai isteri, maka isteri tersebut tidak boleh dinikahi oleh siapapun. ${ }^{33}$ Menurut al-Sarakhsi (w.490 $\mathrm{H})$, dalam kasus al-mafqud ini, orang yang hilang tidak dapat menerima warisan, karena mereka tidak dapat dipastikan hidup. Alasan mereka, istiṣhāb menjadi hujjah bukan dalam bentuk penetapan melainkan penolakan (li al-daf'i). Menurut Abu Hanifah (w.150 H), seperti yang dikutip oleh Sarakhsi, jika seseorang menuntut harta warisan dari ayahnya yang telah meninggal dunia dengan membawa dua orang saksi, lalu saksi tersebut menyatakan bahwa lelaki itu adalah anak

33 Al-Bannanī, Hashiyah al-Bannani 'alā Matn Jam' al-Jawami' (Semarang, Toha Putra, tt.) Vol. II. 349; Muhammad Abū Zahrah, Ușül al-Fiqh (Mesir: Dār al-Fikr al-‘Arabi, 1958), 297; Aḥmad ibn al-Lațīf al-Hațīb, al-Nafahät 'alā Sharh al-Waraqāt (Surabaya: Bungkul Indah, tt.), 150. 
si mayit, maka kesaksian mereka tidak dapat diterima. ${ }^{34}$

Sementara Sarakhsi membagi istiṣhāab menjadi empat macam. ${ }^{35}$ Pertama, istiṣh āb bukm al-hăl disertai adanya keyakinan tentang tidak adanya dalil lain yang mengubahnya. Kedua, istișhāb ḥukm al-hăal setelah adanya dalil yang mengubahnya yang bersifat tetap, dengan jalan penyelidikan dan ijtihad dengan segenap kemampuan. Ketiga, istișhäb hukm al-häl sebelum adanya penyelidikan dan ijtihad dalam mencari dalil yang mengubahnya. Keempat, istișhāb hukkm al-hāl untuk menetapkan hukum awal (ibtidāa). Istiṣhäb dalam bentuk ketiga dan keempat ini, menurutnya, tidak dapat dijadikan hujjah.

Sedangkan al-Ghazzālī memba-gi istișhäb ke dalam empat kategori. ${ }^{36}$ Pertama istișḥäb baräă al-zimmah, kedua istișhäb al-umum al-nash, ketiga istiṣhäb ḥukm dāl al-shar' 'alā thubütih wa dawāmih, dan keempat istișhäb al-ijmä’ fi mahäal alkhiläf. Al-Shawkānī (w.1255 H), sama seperti al-Sarakhsi dan al-Ghazzālī, juga membagi istișhäb menjadi empat yakni istișhäb mà däl al-aql wa shar' 'alā thubutib

34 Al-Sarakhsi, Ușūl al-Sarakhsi (Beirut: Dār alMa'rifah, 1372 H), 225-226.

35 Al-Sarakhsi, Ușül al-Sarakhsi, 225-226.

36 Abū Hamid al-Ghazzālī, al-Mustaşfā Fì Tlm alUșūl, 159-160. wa dawamih, istișhäb al-așl, istișhäb al-hukm al-aql, istișhäb al-dalìl ma'a ịtimäl almu'aridị. Pada akhirnya, istișhāb yang telah terkonstruksi secara jelas dan rinci ini kemudian melahirkan beberapa kaedah umum yaitu al-yaqin là yuzäl bi al-shakek, alașl barä'ah al-dhimmah, al-așl fi al-ashyā' alibähah, dan al-aṣl baqā' mà kāna 'alā mà kàna.

\section{Macam-Macam Istiṣh āb}

Pembagian istișhāb ini didasarkan pada pembagian yang dilakukan oleh Abū Zahrah dan al-Sarakhsi sebagai berikut. ${ }^{37}$

\section{Istișhäb al-Ibähaha al-Ashliyyah}

Istișhāb yang didasarkan pada hukum asal suatu yaitu mubah. Hal ini didasarkan pada Surah Al-Baqarah Ayat 29 "Dialah yang menjadikan segala yang ada di muka bumi ini untuk kalian". Al-Ṭabārī memaknai ayat tersebut bahwa segala sesuatu yang ada di bumi ini diciptakan oleh Allah SWT. untuk manusia agar digunakan demi kebaikan dan kemaslahatan mereka. ${ }^{38}$ Dari ayat tersebut pula muncul kaidah

37 Muhammad Abū Zahrah, Ușül Fikìih (Beirut: Dār al-Fikr, t.th), 297-298. Lihat juga al-Sarakhsi, Ușül al-Sarakhsi, 224.

${ }^{38}$ Muḥammad Ibn Jarīr al-Ṭabarī, Jāmi' al-Bayān fì Ta'mill al-Qur'ān (Beirut: Mu'assasah al-Risālah, 2000), 426. 


$$
\text { الاصل في الاشياء الاباحة } 39 .
$$

Pernyataan segala yang ada di bumi diperuntukkan bagi kebaikan manusia dimaknai 'Abd al-Wahhāb Khallāf bahwa segala yang ada dibumi boleh untuk dimanfaatkan. ${ }^{40}$

Kata al-Ashya' dimaknai lebih kepada urusan muamalah. Sehingga dalam hal yang bersifat muamalah segala hal boleh dilakukan sampai ada dalil yang menghendaki ketidakbolehannya. ${ }^{41}$ Dapat dipahami pula bahwa dalam bidang muamalah, hukum Islam lebih bersifat fleksibel dan lentur. Ijtihad terbuka lebar dalam ranah ini. Berbeda dengan ranah ibadah yang pada asalnya adalah haram dilakukan sampai ada petunjuk untuk melakukannya. ${ }^{42}$ Dalam bidang ibadah tidak ada inovasi, melainkan tunduk dan patuh.

\section{Istiṣhāb al-Bara ah al-Ashliyyah}

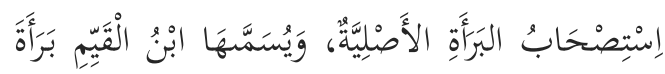

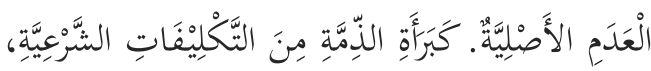

39 'Abd al-Ghanī Kafrāwī dan Aḥmad Mukhtār Maḥmūd, Muḥādrāt fì Ușūl al-Fiqh (Kairo: Jāmi’āt al-Azhār Kuliyyāt Dirāsāt al-Islāmiyyāt, 2002), 147.

40 'Abd al-Wahhāb Khallāf, Ilm Ușūl al-Fiqh, 92.

41 'Alī Hasaballāh, Ușūl al-Tashri' al-Islāmì, 197.

42 Kaidah yang menyatakan hal ini bahwa الاصل في العبادة التحريم Hal senada dikemukakan al-Shātibî̀

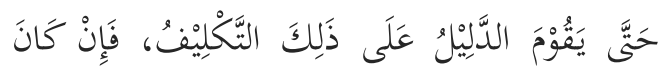

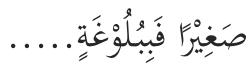

Istișhāb al-bara'ah al-așliyyah atau diistilahkan Ibn al-Qayyim dengan bara'ah al-'adam al-așliyah adalah seperti terbebasnya manusia dari tuntutan syarak. Sampai ada petunjuk yang menghendaki dilakukannya perintah tersebut. Hal ini sebagaimana anak kecil yang tidak terkenan pembebanan apapun sampai ia baligh. Baligh merupakan dalil terjadinya pembebanan sehingga manusia baligh disebut dengan mukallaf.

Istișhāb jenis kedua ini pada prinsipnya menghendaki bahwa setiap orang pada dasarnya terbebas dari segala jenis beban dan tanggungan apapun. Kaidah yang muncul dari jenis ini adalah 43 Dalam bidang ekonomi misalnya, setiap orang terbebas dari utang, sampai ada dalil yang menunjukkan bahwa ia berutang. Oleh karena itu, jika seseorang ditagih utang, maka pada dasarnya ia berhak

bahwa الاصل فن العبادات بالنستة الى المكلف التعبد دون الالتفات الى الماتل

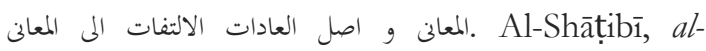
Munväaqaāt fì Ușül al-Aḥkām, 221.

${ }^{43}$ Kaidah tersebut bermakna pada dasarnya setiap manusia terbebas dari tanggungan. Lihat alShayrāzī, al-Lamh fì Ușūl al-Fiquh (Beirut: Dār alKutub al-'Ilmiyyah, 1985), 123. 
menolak sampai ada bukti bahwa penagih membawa bukti bahwa ia berutang.

3. Istișhāb ma dalla al-Shar' aw al-'Aqli 'alā Wujūdì

$$
\begin{aligned}
& \text { إسْتِصْحَابُ مَا دَلَّ الشَّرْعَ أَوِ العَقْلَ عَلَى وُجُجودِهِ. }
\end{aligned}
$$

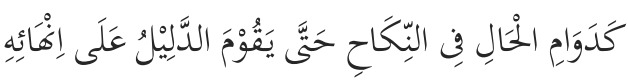

Istișhāb jenis ketiga ini seperti tetapnya status perkawinan seseorang sampai ada petunjuk bahwa perkawinannya telah selesai.

\section{Istiṣhāb al-hukem}

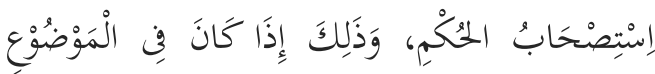

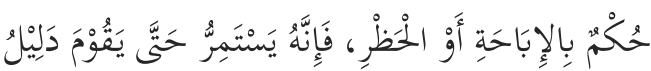

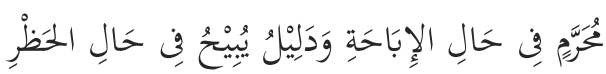

Menerapkan hukum pada masa lalu untuk masa sekarang, sebelum ada petuntuk untuk tidak menggunakannya lagi. ${ }^{44}$ Kaidah turunan pada macam الاصل بقاء ماكان yang keempat ini adalah Status kepemilikan atas harta benda tetap pada pemilik semula sampai ada bukti bahwa harta benda tersebut telah berpindah tangan.

5. Istișhāb al-Wașf

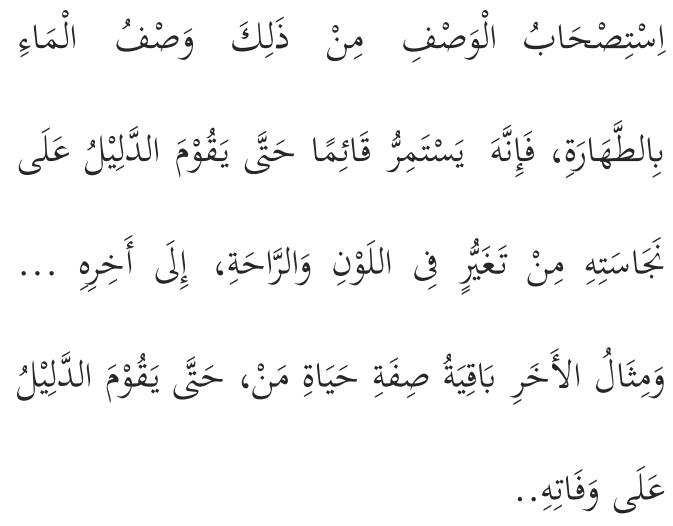

Penetapan hukum atas tetapnya sifat yang ada sebelumnya. Misalnya air suci tetap dihukumi sebagai air suci sepanjang tidak ada bukti bahwa ia telah berubah menjadi najis. Begitupula tetap dianggap hidup seseorang yang hilang sampai ada bukti bahwa orang hilang tersebut telah meninggal. Contoh lainnya adalah tidak batalnya wudu seseorang disebabkan keraguan yang muncul, apakah sudah batal ataukan belum.

Pada gradasi yang kelima ini muncul

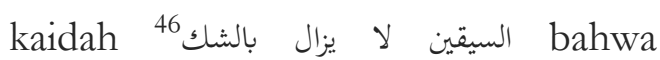
keyakinan tidak bisa dikalahkan oleh keraguan. Dalam hal ini pula, al-Shāfi'i mengeluarkan kaidah

$$
\text { ان ما ثبت بيقين لا يرتفع الا بيقين } 47
$$

bahwa suatu hukum yang ditetapkan berdasarkan keyakinan tidak akan luntur kecuali telah muncul

\footnotetext{
${ }^{44}$ Al-Ghazzālī, al-Mustașfā, 159.

45 Al-Suyūțī, al-Ashbāh wa al-Nazà̄ìr (Beirut: Dār al-Kutub al-'Tlmiyyah, 1403 H), Vol.1. 51.
} 
keyakinan baru yang mengubahnya.

Arak yang semula secara meyakinkan

dihukumi haram manakala telah

berubah menjadi cuka maka menjadi

halal. Berubah menjadi cuka adalah

keyakinan baru yang mengubah

keyakinan lama tentang keharaman

arak.48 Dalam hal ini pula ada kaidah

الحكم يدور مع علته و سببه وجودا و عدما 49.

\section{Kehujjahan Istișhāb}

M. Abū Zahrah menyatakan bahwa mayoritas ulama uṣūl menerima tiga bentuk istiṣh āb, yaitu istiṣh āb al-ibāhah alașliyah, istișhāb bara'ah al-așliyah, dan istiṣhāb al-ḥukm. ${ }^{50}$ Sementara macam istiṣhāb al-wașf, terjadi silang pendapat sebagai berikut.

Pertama, ulama Mālikiyah, al-Shāfi'iyah seperti al-Muzannī, al-Ṣayrāfī, alḤaramayn, al-Ghazzālī, dan Ḥanābilah menyatakan bahwa istișhāb al-wașf dapat dijadikan sebagai dalil hukum secara mutlak, baik ithbāt maupun daf. ${ }^{51}$ Contohnya dalam hal orang yang hilang dan tidak diketahui tempatnya. Orang tersebut tetap dihukumi hidup, sehingga hak warisnya tetap dilindungi dan

\footnotetext{
48 Abū Zahrah, Ușūl al-Fiqh, 304.

49 Muḥammad Ibn Abī Bakr al-Dimasyqū, I'lām alMuwaqqi'in, 104.

50 Abū Zahrah, Ușūl al-Fiqh, 299-300.
}

dianggap ada, baik sebagai pewaris maupun ahli waris. Kedua, ulama Mālikiyah dan Ḥanafiyah hanya menerima istiṣhāb al-wașf dalam hal mempertahankan hukum yang ada (daf) namun menolak istișhāb al-wașf dalam hal menetapkan hukum (ithbāt)

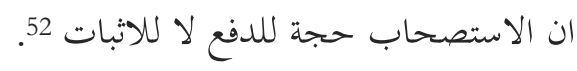

Dalam kasus orang yang mafqūd di atas, menurut Mālikiyah dan Hanafiyah ia tetap dianggap hidup sehingga ia masih dianggap sebagai suami atau istri dan harta benda masih dianggap miliknya. Sementara jika posisinya sebagai ahli waris, ia tidak serta merta mendapatkan hak waris namun bagiannya ditangguhkan (manqüf) sampai benar-benar diketahui kabar beritanya. Status hukum orang yang mafqūd diserahkan sepenuhnya kepada pengadilan.

Selain kedua pendapat tersebut, menurut Muștafā Sa’̄id al-Khān terdapat kelompok lain yang terdiri dari sebagaian ulama Ḥanafiyah dan ulama al-Shāfi'iyah, Abū Husayn al-Bașri, dan sekelompok ulama mutakallimin menolak menggunakan istișhāb.53 Mereka berargumen bahwa halal haram hukum

\footnotetext{
51 Al-Amidī, al-Iḥkàm fì Ușūl al-Ahkeàm (Beirut: Dār al-Kutub al-'Ilmiyyah, 1983), Vol. 4, 172. 52 'Abd al-Wahhāb Khallāf, Tlm Ușūl al-Fiqh, 93. ${ }^{53}$ Mușțafā Sa'īd al-Khanī, al-Kāfì wa al-Wäfì fì Ușūl al-Fiqh, 203.
} 
syarak didasarkan pada teks yang nyata dalam Al-Qur'an dan Hadis. Bagi kelompok ketiga ini, seseorang yang beramal menggunakan istiṣhāb sama dengan beramal tanpa dalil, sehingga tertolak. ${ }^{54}$ Lebih dari itu, 'Abd al-Wahhāb Khalāf menyatakan bahwa para ulama yang menolak istiṣhāab al-wașf disebabkan karena istișhāb tersebut didasarkan asumsi spekulatif, bukan berdasarkan fakta. Sedangkan para usüliyyūn yang menerima istiṣhāb sebagai dalil hukum, menempatkannya pada posisi terakhir ketika tidak ditemukan dalil lain yang menjelaskannya. Hal ini disebabkan oleh karena istiṣhāb didasarkan pada status hukum yang sudah ada yang bergerak dinamis mengikuti perubahan situasi dan kondisi,

Lebih dari itu, menanggapai prokontra tersebut, al-Amidī lebih memilih untuk menggunakan istișhāb sebagai dalil hukum. Ia berpendapat bahwa hukum pada masa lalu memunculkan dugaan kuat bahwa hukum tersebut terus berlaku hingga sekarang. Alasan lain ia menggunakan istiṣhāb yaitu ketetapan ijmak bahwa jika seseorang ragu-ragu sudah berwudu atau belum maka orang tersebut tidak boleh melakukan salat, namun jika keraguan itu sudah batal atau belum maka yang diyakini adalah ia telah berwudu dan belum batal. Hal lain yang ia jadikan alasan adalah adanya kaidah bahwa dugaan akan tetapnya sesuatu lebih kuat dari pada dugaan akan berubahnya sesuatu. Al-Amidīi kemudian berkesimpulan bahwa asas istiṣhāb adalah asal sebuah hukum adalah ketiadaan dan tetapnya suatu menurut hukum yang telah ditetapkan sebelumnya. 55

\section{Istișhāb Dan Problematika Kontemporer}

Aktualisasi dan reformulasi hukum Islam digalakkan oleh banyak tokoh Islam. Hal ini dilakukan dalam rangka menjawab tuntutan zaman yang senantiasa berubah. Jika hukum Islam tidak dapat menjawab kebutuhan terebut tentu saja berimbas pada ketidakterlananya cita-cita Islam yaitu Șälị̣ li kulli zamān wa makān. Di sisi lain, pergerakan itu berada di ruang lingkup yang bagaimana masih menjadi perdebatan sepanjang masa.

Al-Ṭūfì misalnya mengatakan bahwa dalam hal ibadah mahdah, aturan tunduk pada nash-nash yang ada, sementara dalam bidang muamalah, kemaslahatan

${ }^{55}$ Al-Amidī, al-Ị̣kām fì Ușül al-Aḥkàm, 173-174. 
menjadi sumber tertinggi. ${ }^{56} \mathrm{Hal}$ senada diungkapkan Subḥi Mahmasanī, pembaruan hukum Islam dapat dilakukan dalam bidang muamalah. Sedangkan dalam bidang 'ubüdiyyah, ketentuan nash menjadi mutlak digunakan, meskipun situasi dan kondisi berubah seperti apapun. ${ }^{57}$

Seperti dikatahui, hukum Islam terbagi menjadi dua macam, ibadah dan muamalah. Dalam bidang ibadah bersifat ta'abbudì dan ghayr ma'qūl al-ma'nā, tidak ada perintah maka tidak ada ibadah. Dengan kata lain, ibadah hanya dilakukan jika ada perintah nyata dalam nash, dalam hal ini akal menjadi tidak berlaku. Yang berfungsi adalah ketunduk-pasarahan manusia sebagai hamba. Kaidah yang belaku adalah الاصل في العبادة التحري. Sedangkan dalam bidang muamalah (ghayr mahdah) bersifat ta'aqquī (ma'qūl al-ma'nà). Sehingga tuntutan ijtihad dalam hal kedua ini menjadi perlu untuk dilakukan. Tujuannya adalah membumikan syariat Islam sehingga Islam tetap responsive terhadap perubahan kondisi dan situasi. Adapun aktivitas ijtihad yang dilakukan didasarkan perangkat metode yang ada.

${ }^{56}$ Najm al-Dīn al-Ṭufí, Sharh al-Arba ìn al-Nawain taḥīiq Mușțafā Za’̄id dalam Muāțafā Za'̄̄d, alMașlahah fi al-Tashri al-Islämi wa Najm al-Dìn alTūfì (Kairo: Dār al-Fikr al-'Arabī, 1964), 125-dst.
Kaidah yang berlaku bagi macam yang kedua ini adalah الاصل في الاشياء الاباحة.

Istiṣhāab sebagaimana dijelaskan di awal, dijadikan sebagai dalil hukum yang digunakan pula untuk menetapkan aturan demi terwujudnya kemaslahatan manusia. Berikut beberapa kasus kekinian yang dapat diselesaikan menggunakan konsep istișhāb.

\section{Bidang Hukum Perkawinan Dan \\ Keluarga}

Asal hukum seorang laki-laki dan perempuan adalah bebas, tidak ada ikatan hak dan kewajiban. Hal tersebut berlaku selama tidak ada bukti bahwa status hukum keduanya berubah yaitu adanya akad perkawinan yang dibuktikan pula dengan adanya akte perkawinan (akta nikah). Berkaitan dengan UU No. 1/1974 yang menyatakan bahwa perkawinan yang sah secara hukum negara dibuktikan dengan akta nikah melalui pencatatan perkawinan. ${ }^{58}$ Munculnya akta pencatatan perkawinan ini sekaligus sebagai awal mula terjadinya hak dan kewajiban seorang laki-laki dan perempuan (suamiisteri). Dengan demikian, tanpa adanya pencatatan perkawinan, perkawinan jenis apapun (kawin sirri, kawin kontrak, nikah

\footnotetext{
57 Subhi Mahmasani, Filsafat Hukum Islam (Bandung: PT. al-Ma'arif, 1976), 118-119.

58 Lihat UU No. 1 Tahun 1974 tentang Perkawinan Pasal 2 Ayat 1 dan 2.
} 
wisata) dianggap tidak pernah ada (tidak sah).

Pencatatan perkawinan merupakan ijtihad ulama kontemporer berupa pembaruan hukum dan sekaligus keberanjakan dari fikih klasik. ${ }^{59}$ Maksud dari pada pencatatan perkawinan adalah untuk mengeliminir terjadinya kemadaratan. Hal ini pun sesuai dengan kaidah menolak madarat lebih didahulukan dari pada menarik kemasalahatan. ${ }^{60}$

Hal serupa juga dapat dijumpai pada masalah aturan batasan umur perkawinan ${ }^{61}$ dan pewaris atau ahli waris yang hilang. Keduanya dapat dianalisa dan dijawab dengan pendekatan istiṣhāab.

\section{Bidang Hukum Pidana}

Sebagaimana dijelaskan di awal, istiṣh āb adalah memberlakukan hukum lama untuk diterapkan pada masa sekarang selama tidak ada hal yang mengubahnya.

\footnotetext{
59 Anwar Hafidzi, "Eksistensi Advokat Sebagai Profesi Terhormat (Officium Nobile) Dalam Sistem Negara Hukum Di Indonesia," Khazanah: Jurnal Studi Islam dan Humaniora 13, no. 1 (2015).

60 'Alī Hasaballāh, Ușül al-Tashrì', 309.

61 Undang-Undang No 1 Tahun 1974 tentang Perkawinan Bab 2 Pasal 7 Ayat (1), Peraturan Menteri Agama No.11 Tahun 2007 tentang Pencatatan Nikah Bab IV Pasal 8, Peraturan Menteri Agama No.11 Tahun 2007 tentang Pencatatan Nikah Bab IV Pasal 7

${ }^{62}$ Lihat KUHAP Butir 3 Huruf c dan UU No. 48

Tahun 2009 tentang Kekuasaan Kehakiman Pasal 8 Ayat (1).
}

Asal segala sesuatu adalah mubah atau boleh sehingga tidak ada sesuatu yang dapat mencegah, melarang, atau bahkan mewajibkannya. Hal ini sejalan dengan asas hukum yang berlaku di Indonesia, yaitu asas praduga tak bersalah. ${ }^{62}$ Seorang terdakwa yang sedang menjalani proses persidangan tidak boleh dihukumi bersalah sampai ada bukti dan diputusan oleh pengadilan bahwa ia telah melakukan tindak pidana. Asas ini, praduga tak bersalah, dalam hukum pidana Islam dikenal dengan asas legalitas ${ }^{63}$, yaitu tidak ada hukum bagi perbuatan orang dewasa sebelum ada aturan yang mengaturnya. Hal ini pun sejalan dengan asas nullum delictum nula poena sine praevia leg poenali. ${ }^{64}$

Oleh karena itu, tindakan main hakim sendiri yang kerap terjadi di Indonesia, baik secara hukum positif maupun istișhāb tidak dapat dibenarkan. Contoh kasus adalah pengarakan seorang laki-laki dan perempuan yang terjadi di Tangerang

63 Dalam aturan hokum pidana Islam, asas legalitas ini dinyatakan لا حكم لافعال العقلاء قبل ورود النص. Baca; 'Abd al-Qādir 'Awdah, al-Tashrī' al-Jinà'î fí alIslām Muqāranan bi al-Qānūnì al-Wậ̀ 'i (Beirut: Dār al-Kutub al-'Ilmiyyah, t.th), 122.

64 Artinya bahwa seseorang tidak dapat dinyatakan bersalah sebelum pengadilan menyatakannya. Baca; Abdul Ghani Abdullah, "Eksistensi Hukum Pidana Islam dalam Reformasi Hukum Nasional" dalam M. Amin Suma, Pidana Islam di Indonesia, Peluang, Prospek, dan Tantangan (Jakarta: Pustaka Firdaus, 2001), 246. 
beberapa waktu yang lalu, bahkan dilakukan pula oleh apparat negara. Hal itu terjadi hanya karena asumsi bahwa keduanya telah berbuat asusila, tanpa ada bukti dan bahkan saksi. ${ }^{65}$

Pun pula dalam masalah ekonomi dan kehidupan sosial. Misalnya ketika terjadi sengketa, maka diterapkan dalil istiṣh ăb, yaitu hukum diberlakukan sebagaimana keadaan semula kecuali ada hal lain yang menghendaki perubahan. Seorang penggugat harus membawa bukti, sebab bagi tergugat hanya perlu mengingkarinya saja. Jika bukti tidak ada maka jelas tergugatlah yang menang. ${ }^{66}$

Sikap tuduh-menuduh yang juga kerap terjadi di Indonesia, bisa dieliminasi dengan pemahaman yang utuh terhadap istiṣhāb. Bahwa pada dasarnya setiap orang tidak bersalah, bahwa pada dasarnya setiap orang adalah bebas untuk melakukan apapun, dan bahwa pada dasarnya setiap orang tidak mempunyai hak dan kewajiban yang melingkupinya. Menuduh orang lain mencuri, korupsi, dan tuduhan yang lainnya tanpa bukti sama saja menciderai asas awal hukum Islam. Selain juga ia melanggar pasal

${ }^{65}$ Lihat dalam http://www.tribunnews.com/metropolitan/201 7/11/14/heboh-pasangan-ditelanjangi-diarakmassa-inilah-6-fakta-sebenarnya-ternyata-tidakberbuat-mesum

https://www.republika.co.id/berita/nasional/jab odetabek-nasional/17/11/14/oze564-pasangan- fitnah dan pasal melakukan perbuatan tidak menyenangkan yang dapat dijerat dengan hukum pidana.

\section{Kesimpulan}

Istiṣhāb adalah pemberlakukan hukum lama pada masa sekarang, sebab tidak ada dalil hukum lain yang menghendaki perubahan. Penolakan atas istiṣhāb terjadi karena istiṣhāb masuk dalam kategori sumber hukum yang dipersilihkan. Para penolak istiṣhāb mendasarkan argumentasinya bahwa menggunakan istiṣhāb sama saja beramal tanpa dasar. Meskipun demikian, mayoritas ulama menggunakan istișhāa sebagai dasar hukum -terakhir- setelah berusaha mencari ketentuan hukum pada sumber yang disepakati. Pada aplikasinya, melalui tulisan ini, terbukti bahwa istișhāb masih sangat relevan diterapkan sebagai alternatif pemecahan kasus hukum, baik dalam bidang hukum keluarga, hukum pidana, ekonomi, dan keperdataan.

\section{Daftar Bacaan}

Al-Qur'an

'Awdah, 'Abd al-Qādir. t.th. al-Tashrì' alJinä̀' fì al-Islàm Muqäranan bi al-

diduga-berbuat-mesum-diarak-polisi-amankan-6orang

66 dalam kaidah disebutkan البينة على المدعى و اليمين على lihat pula al-Shāfi'1̄, al-Umm (Beirut: Dār alMa'rifah, 1393), I: 56. 
Qānūnì al-Waḍ̂. Beirut: Dār al-

Kutub al-'Ilmiyyah.

Abdullah, Abdul Ghani. 2001. "Eksistensi

Hukum Pidana Islam dalam

Reformasi Hukum Nasional"

dalam M. Amin Suma, Pidana

Islam di Indonesia, Peluang, Prospek,

dan Tantangan. Jakarta: Pustaka

Firdaus.

al-Jawziyyah, Ibn Qayyim. 2003. I'läm al-

Muwaqqi'in 'An Rabb al-'Alamin.

Beirut: al-Maktabah al-'Așriyyah, Vol. 1.

Amidī, Al-. 1983. al-Iḥkām fì Ușūl alAhkeam. Beirut: Dār al-Kutub al'Ilmiyyah, Vol. 4.

Andalusī, Ibn Hazm al-.1992. Al-Iḥkàm Fì

Ușūl al-Ahkām. Kairo: Dār al-

Hadis, Vol V.

Bannanī, Al-. t.th. Hāshiyah al-Bannani 'alā

Matn Jam' al-Jawāmi'. Semarang,

Toha Putra, Vol. II.

Bașri, Muḥammad ibn 'Alī al-. 1965. alMu'tamad Fì Ușūl al-Figh. Damshiq: Dār al-Fikr, Vol II.

Bukhārī, 'Abd al-'Azīz ibn Muhạmmad al-

. t,th. Kashf al-Asrār 'An Ușūl

Fakbr al-Islam al-Bazdwi. Beirut:

Dār al-Kitāb al-'Arabī, Vol. 2

Coulson, Noel J. 1987. A History of Islamic

Law. Edinburgh: University Press.

Fairuzabadī, Ibrāhīm ibn 'Alī al-. 1985. alLuma' Fi Ușūlal-Fiqh. Beirut: Dār al-Kutub al-'Ilmiyah.

Ghazzālī, Abū Ḥamīd Muḥammad ibn Muhammad al-. 1993. AlMustașfä Min Tlm al-Ușūl. Beirut: Dār al-Kutub al-'Ilmiyah, Vol. 2

Hafidzi, Anwar. "Eksistensi Advokat Sebagai Profesi Terhormat (Officium Nobile) Dalam
Sistem Negara Hukum Di

Indonesia." Khazanab: Jurnal

Studi Islam dan Humaniora 13, no.

1 (2015).

Hanbāl, Aḥmad ibn. 1993. Musnad Aḥmad Ibn Hanbāl. Beirut: Dār al-Kutub al-Islāmiyyah, Vol. IV.

Hasaballāh, 'Alī. t.th. Ușūl al-Tashrì' alIslāmì. Kuwait, Dār al-Ma'ārif.

Hasan, Ahmad. 1984. Pintu Ijtihad Sebelum Tertutup. Bandung: Pustaka.

Hasān, Husayn Hamīd. 1971. Naẓariyah alMaṣlaḥah. Kairo: Dār al-Naḥ̣̣ah al-'Arābiyah.

Hațīb, Aḥmad ibn al-Lațîf al-. t.th. alNafahāt 'alā Sharh al-Waraqāt. Surabaya: Bungkul Indah.

http://www.tribunnews.com/metropolit an/2017/11/14/hebohpasangan-ditelanjangi-diarakmassa-inilah-6-fakta-sebenarnyaternyata-tidak-berbuat-mesum

https://www.republika.co.id/berita/nasi onal/jabodetabeknasional/17/11/14/oze564pasangan-diduga-berbuatmesum-diarak-polisi-amankan6-orang

Imām, Muhammad Kamal al-Dīn. 1996. Ușūl al-Fiqh al-Islāmì. Beirut: Muassasah al-Jāmi'iyyah li aldirāsah wa al-Shu'ūn wa alTawzi'.

Kafrāwī, 'Abd al-Ghan̄̄ dan Aḥmad Mukhtār Maḥmūd. 2002. Muhāệāt fì Ușūl al-Fiqh. Kairo: Jāmi'āt al-Azhār Kuliyyāt Dirāsāt al-Islāmiyyāt.

Khallāf, 'Abd al-Wahhāb. 2004. TIm Uṣūl al-Figh. Jeddah: al-Haramayn. 
1955. Mașādir al-Tashri' al-Islāmi fi

mà là Nașa fi hā. Kairo: Ma’had al-Dirāsāt al-'Arabiyyah al'Āliyah.

KUHAP

Madhkūr, Muhammad Salam. 1992. alIjtihäd Fì Tashrì al-Islämì. Kairo: Dār al-Nahḍah al-'Arabiyah, Vol I.

Mahmasani, Subhi. 1976. Filsafat Hukum Islam. Bandung: PT. al-Ma'arif.

Mubarok, Jaih. 2002. Metodologi Ijtihad Hukum Islam. Yogyakarta: UII Press.

Musarawah, 'Awni Ahmad Muhammad. 2003. al-Istișhāb, Huijizyatub $W a$ Athrub Fi al-Ahkàm al-Fiqhiyyah. Nablis: t.tp.

Nawāwī, Al-. 1986. Sharh Muslim. Beirut: Dār al-Kutub al-'Ilmiyah, Vol. IV

Nusayfī, Hafịz al-Dīn al-. 1986. Kashf alAsrār. Beirut: Dār al-Kutub alIlmiyah, Vol II.

Peraturan Menteri Agama No. 11 Tahun 2007 tentang Pencatatan Nikah

Rab'iyyah, 'Abd al-'Azīz al-. 1979. Adillāt al-Tashri’ al-Mukbtalaf fi al-Ihtijāj fỉhā. Beirut: Muassasāt al-Risālāt.

Ridwan. "Istiṣhāb dan Penerapannya dalam Hukum Islam”, al-Manähij Jurnal Kajian Hukum Islam, Vol. v. No. 1, Januari 2011.

Rushd, Ibn. t.th. Bidāyah al-Mujtabid wa Nihāyah al-Muqtașid. T.tp: Dār alKutub al-'Arabiyah.

Sarakhsi, Al-. 1372 H. Ușūl al-Sarakhsi. Beirut: Dār al-Ma'rifah.

Shāfi'ì, Al-. 1325 H. al-Umm. Kairo: tp, Vol. VII.

Shāṭibī, Abū Isḥaq Ibrāhīm ibn Mūsā alLakhmi Al-. 1341 H. Al-
Muwāfaqāt fi Ușūl al-Ahkām. Kairo: Dār al-Fikr, Vol. I.

Shawkānī, Muhammad Ibn 'Alī Ibn Muhammad al-. 1992. Irshäd alFukbūl ilā Tahquiq Tlm al-Ușūl. Beirut: Dār al-Fikr, Vol. 1

Shayrāzì, Al-. 1985. al-Lamb fì Ușūl al-Fiqh. Beirut: Dār al-Kutub al'Ilmiyyah.

Subkī, 'Alī 'Abd al-Kāfĩ al-. 1404 H. alIbhāj. Beirut: Dār al-Kutub al'Ilmiyyah.

Suyūțī, Al-. 1403 H. al-Ashbāh wa alNazà̄îr. Beirut: Dār al-Kutub al'Ilmiyyah, Vol.1.

Tabarī, Muḥammad Ibn Jarīr al-. 2000. Jämi' al-Bayān fì Ta'wül al-Qur'àn. Beirut: Mu'assasah al-Risālah.

Tūfí, Najm al-Dīn al-. 1964. Sharh alArbain al-Nawain tahqīi Muștafā Za'īd dalam Muātafā Za'ìd, al-Mașlahah fi al-Tashri' alIslämi wa Najm al-Din al-Tüfí. Kairo: Dār al-Fikr al-'Arabī.

Tuwana, Muḥammad Mūsā. 1971. alIjtihàd. Mesir, Dār al-Kutub alHadīthah.

UU No. 1 Tahun 1974 tentang Perkawinan.

UU No. 48 Tahun 2009 tentang Kekuasaan Kehakiman

Za’id, Muștafā. 1954. al-Mașlahah fi alTashri' al-Islami wa Najm al-Din alȚüfì. ttp: Dār al-Fikr al-'Arābī.

Zahrah, Abū. t.th. Tärikh al-Madhähib alIslāmiyah. Beirut: Dār al-Fikr, Vol. II. t.th. Ușūl Fiqh. Beirut: Dār al-Fikr. Zarqā, Muṣțafā Muḥammad al-. 2000. Hukum Islam dan Perubahan Sosial. Jakarta: Rioracipta. 
64 SYARIAH: Jurnal Hukum dan Pemikiran Volume 18, Nomor 1, Juni 2018, blm. 45-64 